\title{
THE ULTRASONIC EFFECT ON OBTAINING AND PROPERTIES OF OSTEOPLASTIC POROUS COMPOSITES
}

\author{
Volodymyr Skorokhoda ${ }^{1,}{ }^{凶}$, Iryna Dziaman ${ }^{1}$, Galyna Dudok${ }^{1}$, \\ Taras Skorokhoda ${ }^{1}$, Mykhailo Bratychak, $\mathrm{Jr}^{1}{ }^{1}$, Nataliya Semenyuk ${ }^{1}$
}

https://doi.org/10.23939/chcht13.04.429

\begin{abstract}
The grafted copolymerization of 2-hydroxyethyl methacrylate to polyvinylpyrrolidone in the presence of mineral fillers (hydroxyapatite, montmorillonite and wollastonite) under ultrasound has been investigated. The effect of ultrasound, nature and amount of mineral filler on the polymerization rate and composition of copolymers has been determined. Ultrasound substantially intensifies the polymerization process and actively affects the formation of the copolymer composition. Under its action, a porous structure of composites is formed, even without adding special foaming agents. The obtained results were used to improve the technology of obtaining osteoplastic porous composites.
\end{abstract}

Keywords: 2-hydroxyethyl methacrylate, polyvinylpyrrolidone, ultrasound, porous composites, mineral filler.

\section{Introduction}

Ultrasound energy is often used in the chemical industry to improve and intensify the technological processes. Ultrasound is acoustic vibrations with the frequencies of $2 \cdot 10^{4} \mathrm{~Hz}$ and higher $[1,2]$. When propagating in any phase, including a liquid one, such vibrations cause a range of specific effects, in particular ultrasonic cavitation and the initiation of chemical reactions [3]. The mechanism of ultrasound influence is very complex and versatile, which does not give the possibility to develop a single common theory that would allow correctly explain the phenomena of ultrasound action. Therefore, for each particular case, it is necessary to carry out wide-ranging studies of ultrasound effect on the chemical reaction proceeding, the structure and properties of compounds and materials formed as a result of physical and chemical transformations.

In the chemical reactions under the influence of ultrasound a number of factors, in particular, temperature

\footnotetext{
${ }^{1}$ Lviv Polytechnic National University,

12, Bandera St., 79013 Lviv, Ukraine

凶vskorohoda@yahoo.com

(c) Skorokhoda V., Dziaman I., Dudok G., Skorokhoda T., Bratychak M. Jr., Semenyuk N., 2019
}

and air oxygen are changed; the reaction rates are often high even at relatively low temperatures. Therefore, there is a keen interest in the study of polymerization under ultrasound, because it is expected both simplification of the technology itself and the temperature-time regimes for obtaining polymers and composites. In addition, there are wide opportunities for providing polymers and polymerbased composites the additional extrinsic properties.

The grafted copolymers of polyvinylpyrrolidone (PVP) with methacrylic esters, in particular with 2-hydroxyethyl methacrylate (HEMA), are effectively used in various industries, most often in biomedicine and pharmacy [4]. Such copolymers are used for the production of corrective and therapeutic contact lenses, accommodation lenses, polymeric systems (including membrane ones) for regulated drug release, dental materials and products [5-7]. PVP in the initial mixtures and copolymers allows to effectively obtain silver nanoparticles in the hydrogels and composites structure without applying toxic reducing agents and to provide the products with antifungal and antibacterial activity [8]. Recently, the copolymers with mineral fillers have been used as osteoplastic composites for the replacement of damaged bone tissue $[8,9]$. Copolymers fulfil the function of the binder and improve the physico-mechanical properties of the composites. These composites are usually obtained via block polymerization with simultaneous foaming of the initial mixture. Among the mineral fillers, hydroxyapatite (HA) attracts the greatest attention because its structure and composition are close to the bone [10]. However, the technology for obtaining such osteoplastic composites has a significant disadvantage - the synthesis time is large enough (usually 5-15 h) [11]. Therefore, the intensification of the synthesis with the simultaneous improvement of the composite properties is an urgent task in the technology of obtaining such materials.

We expect that the use of ultrasonic vibrations will enable not only to intensify polymerization, but also to modify the structure and properties of polymers. So, the purpose of this work was to investigate the effect of ultrasound on the obtaining of HEMA-PVP based porous 
composites, their structure and properties, and using the obtained results to develop a basic technological scheme for the production of porous composites.

\section{Experimental}

2-Hydroxyethyl methacrylate (HEMA, Bisomer) was vacuum-distilled before use $\left(130 \mathrm{~N} / \mathrm{m}^{2}, 351 \mathrm{~K}\right)$. Benzoyl peroxide (BPO, 97\%, SIGMA) (polymerization initiator) was twice recrystallized from ethanol. The initiator amount was $1 \mathrm{wt} \%$. Polyvinylpyrrolidone (PVP, $\mathrm{MW}=28,000$, AppliChem $\mathrm{CmbH}$ ), polyethylene glycol (PEG-1500, Serva), montmorillonite (MM) $(\mathrm{Na}, \mathrm{K}, \mathrm{Ca})(\mathrm{Al}, \mathrm{Fe}, \mathrm{Mg}, \mathrm{Cr})_{2}\left[\left(\mathrm{Si}_{4} \mathrm{O}_{10}\right](\mathrm{OH})_{2} \cdot \mathrm{H}_{2} \mathrm{O}\right.$ (Fluka) and wollastonite (WS) $\mathrm{CaSiO}_{3}$ were used as received. Hydroxyapatite (HA) $\mathrm{Ca}_{10-\mathrm{x}}\left(\mathrm{PO}_{4}\right)_{6}(\mathrm{OH})_{2}$ with the particles size of $0.05-1.25 \mathrm{~mm}$ was synthesized at the Department of Silicates Technology of Lviv Polytechnic National University.

Typically, porous copolymers were obtained via block copolymerization. PEG-1500 polyethylene glycol was used for the foam stabilization.

Block copolymerization under the influence of ultrasound was carried out using the ultrasonic device "Volna" (Fig. 1), the model UZTA-0.4/22-OM, the frequency of mechanical vibrations is $22 \pm 1.65 \mathrm{kHz}$, maximum power is $400 \mathrm{~W}$, power regulation range is 30 $100 \%$. The ratio of the magnetostrictor diameter to the diameter of the reactor is not less than 0.5 . We loaded the reactor with the synthesized mixture, lowered the magnetostrictor to contact with it, turned on the instrument and set the required intensity of ultrasound.

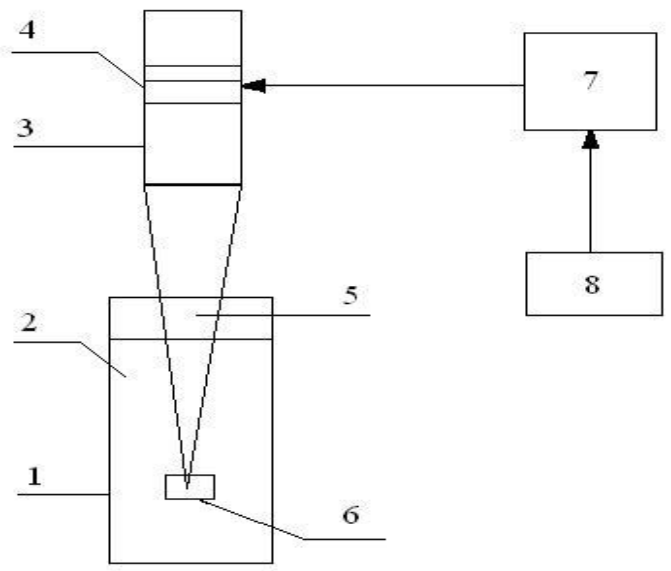

Fig. 1. Schematic diagram of the ultrasonic technological device "Volna": reactor (1); the synthesized mixture (2); ultrasonic vibrating system (3); converter of electrical oscillations (4); waveguide system (5); a tool for introducing ultrasonic waves into the medium (6); electric generator (7); control and automation system (8)
The polymerization rate was investigated by the chemical method in accordance with the change in amount of unreacted monomer during polymerization [12]. If argentum salts were added to the initial mixture, then silver nanoparticles were obtained in the structure, and the composites acquired the antifungal and antibacterial properties [9].

Infrared spectroscopy was performed on a Thermo Nicolet Nexus 870 FTIR spectrometer at room temperature using liquid mixtures and pressed tablets of copolymer powder and $\mathrm{KBr}$.

The average diameter of pores $\left(d_{p}\right)$ was determined by measuring size of at least 200 pores using MBS- 9 microscope. The structure of the composites was studied using a transmission electron microscope (TEM) JEOL JEM $200 \mathrm{CX}$. The total porosity and composites density were determined using a Manehold method described in [13]. According to this method, the polymer sample is weighted in two immiscible liquids (e.g. heptane and water). Total porosity $(W, \%)$ was calculated as:

$$
\begin{gathered}
W=\frac{V-V_{d}}{V} \cdot 100=\frac{V-\frac{P_{a}-P_{\mathrm{H}_{2} \mathrm{O}}}{d_{\mathrm{H}_{2} \mathrm{O}}}}{V} \cdot 100 \\
V=\frac{P_{\mathrm{H}_{2} \mathrm{O}}-P_{\text {hept }}}{d_{\text {hept }}-d_{\mathrm{H}_{2} \mathrm{O}}}
\end{gathered}
$$

where $V_{d}$ and $V$ are volumes of dry substance and sample, impregnated with water in air, respectively, $\mathrm{cm}^{3} ; P_{a}, P_{\mathrm{H}_{2} \mathrm{O}}$ and $P_{\text {hept }}$ are weights of the sample in air, in water and in heptane, respectively, g; $d_{\mathrm{H} 2 \mathrm{O}}$ and $d_{\text {hept }}$ are densities of water and heptane, respectively, $\mathrm{g} / \mathrm{cm}^{3}$.

The compression strength of the materials was determined by the standard method using the universal testing machine "Kimura" of RT-601U type (Japan). To determine the mechanical properties the samples of polymer composites with a diameter of $15 \mathrm{~mm}$ and a height of $10 \mathrm{~mm}$ were used. Relative compression strength was identified during $10 \%$ deformation and was calculated according to the following formula:

$$
\sigma_{10}=\frac{P_{10}}{S}
$$

where $P_{10}$ is a loading during $10 \%$ deformation, N; $S$ is a sample cross-section area, $\mathrm{m}^{2}$.

The amount of unreacted PVP was determined using photocolorimetry $[14,15]$. The method is based on the formation of PVP-iodine colored complex. The efficiency of grafting $(f)$ was calculated as the ratio of the grafted PVP amount to the total amount of PVP in the initial mixture. The degree of grafting $(P)$ was determined as the ratio of the grafted PVP weight to the total weight of the copolymer. 


\section{Results and Discussion}

The composition of the initial mixtures, the synthesis temperature and time to a large extent determine the structure and properties of the composites.

Our previous kinetic investigations of HEMA-PVP thermo-initiated block polymerization [8] demonstrated that depending on the nature of the mineral filler (MM, WS, HA), the polymerization proceeds with different rates. The mixtures with MM and WS are polymerized more rapidly than those containing HA (Fig. 2).

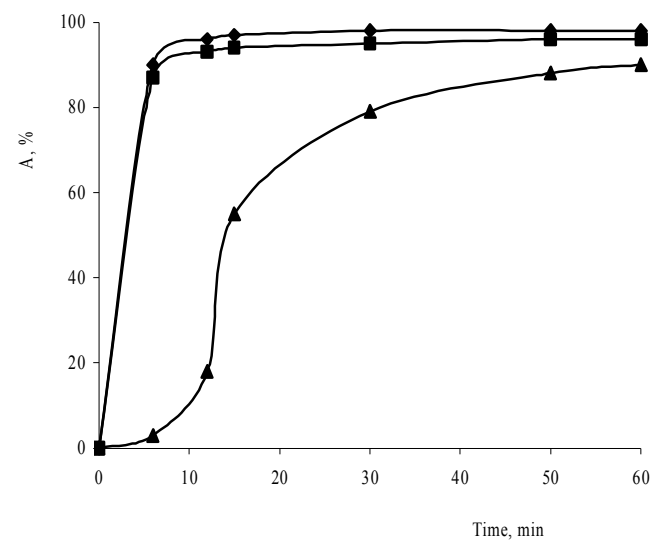

Fig. 2. Monomer conversion degree vs. polymerization time depending on a filler nature: $\mathrm{MM}(\boldsymbol{\nabla})$, WS $(\boldsymbol{\square})$ and $\mathrm{HA}(\mathbf{\Delta})$. Temperature is $328 \mathrm{~K}$;

HEMA : PVP : filler is 70:30:70 (w/w/w)

To our mind, the high reactivity of the mixtures with $\mathrm{MM}$ is provided by the complex structure of its surface with negative and positive charges, due to which montmorillonite can be a catalyst of ionic polymerization [8]. The insignificant decrease in polymerization rate in the presence of hydroquinone as a radical polymerization inhibitor reveals the ionic mechanism of HEMA-PVP polymerization in the presence of MM.

In order to establish the possibility of composites synthesis at moderate temperatures and to intensify the process, polymerization of the mixture under ultrasound was investigated (Table 1).

Homopolymerization of HEMA without a filler does not occur under the experimental conditions. In the presence of PVP without HA, the HEMA mixtures are polymerized with a low rate. Mineral fillers form a heterogeneous medium in the mixtures, which are polymerized very quickly under ultrasonic influence. It is important to note that polymerization is accompanied by the simultaneous foaming of the mixture. This provides additional technical and economic advantages in developing the technological process of obtaining porous composites. The use of ultrasound allows to conduct polymerization at room temperature. The initial rate of polymerization in this case is more than 20 times higher compared with that without ultrasound even if it is carried out at higher temperatures (Table 1). The time for achieving "boundary" conversion is reduced from $2-3 \mathrm{~h}$ to 1-3 min.

When discussing the polymerization behaviour in the investigated systems, it is necessary to take into account that under the action of cavitation energy released in the area of ultrasound action, macroradicals of two types can be formed from PVP macromolecules [2]:

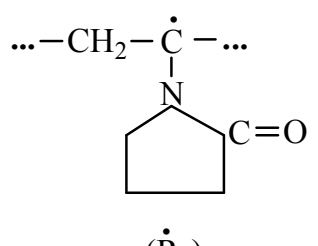

and<smiles>CC[CH]N1CCCC1=O</smiles>

$\left(\dot{\mathrm{R}}_{2}\right)$

Table 1

Ultrasound effect on the polymerization rate

\begin{tabular}{|c|c|c|c|c|c|}
\hline \multicolumn{2}{|c|}{ Composition of polymer-monomer mixture, wt.parts } & \multirow{2}{*}{$\begin{array}{c}V_{p} \cdot 10^{2} . \\
\text { mol/ls }\end{array}$} & $\begin{array}{c}\text { "Boundary" conversion of } \\
\text { monomer, } \%\end{array}$ & $\begin{array}{c}\text { Time to achieve } \\
\text { "boundary" } \\
\text { conversion, } \mathrm{s}\end{array}$ \\
\hline HEMA & PVP & filler & 0 & - & - \\
\hline 70 & 0 & 0 & 2.2 & 90 & 190 \\
\hline 70 & 30 & HA; 70 & $10.4 / 0.42$ & 94 & $50 / 7500$ \\
\hline 70 & 30 & HA; 100 & 12.1 & 96 & 50 \\
\hline 70 & 30 & HA; 150 & 17.5 & 97 & 45 \\
\hline 70 & 30 & WS; 70 & 11.8 & 96 & 45 \\
\hline 70 & 30 & MM; 70 & 16.6 & 95 & 35 \\
\hline
\end{tabular}

Notes: $T=298 \mathrm{~K}$, ultrasound capacity $120 \mathrm{~W}$; values in the denominator are given for the composites without ultrasonic treatment at $328 \mathrm{~K}$ 
These radicals can initiate the formation of respectively grafted<smiles>[R]C(C)CC(C)N1CCCC1=O</smiles>

and block copolymers:<smiles>[R]C(C)CC([R])CC(CC)N1CCCC1=O</smiles>

The participation of PVP in the reactions of copolymers obtaining is confirmed by IR spectroscopy of PVP, polyHEMA and HEMA-PVP copolymer extracted with water and ethanol till the complete removal of unreacted PVP. The results show the presence of PVP characteristic bands of $650,1415,1480 \mathrm{~cm}^{-1}$ in the copolymer spectrum.

So, we can assert that HEMA polymerization in the presence of PVA and mineral fillers occurs in the ultrasonic field both via ionic and radical mechanisms. As a result, it is possible to achieve a high conversion degree of monomer into a polymer for a relatively short time. This fact will significantly intensify the polymerization stage of the porous composites obtaining and increase the process productivity.

The main properties of copolymers, in particular, technological and operational ones, considerably depend on its structure. The properties of PVP with methacrylic esters copolymers are influenced by the copolymer composition, i.e., the molar ratio of the monomer and PVP chain links. Therefore, it was necessary to investigate the influence of nature and quantity of mineral filler, temperature and monomer-polymer composition on the efficiency of grafting $f$ and degree of grafting $P$, as well as on the copolymers composition. The results are presented in Tables 2-3.

The efficiency of grafting (which is defined as the ratio of PVP amount in the copolymer to its amount in the initial mixture) in the case of using WS decreases with an increase in the PVP amount in the initial mixture (Table 2, numerator). In the case of using $\mathrm{MM}$ as the filler, the efficiency of grafting is significantly higher and slightly depends on the initial amount of PVP in the composition (Table 2, denominator). However, the degree of grafting, in contrast to the efficiency, considerably depends on the PVP content. Thus, changing the amount of PVP in the initial mixture, it is possible to regulate the composition, and, consequently, the properties of the copolymers.

Table 2

\section{Dependence of efficiency $f$, degree of grafting $P$ and the copolymers composition on the components ratio in the initial mixture}

\begin{tabular}{|c|c|c|c|c|}
\hline \multirow{2}{*}{ HEMA:PVP:filler, wt.parts } & \multirow{2}{*}{$* \%$} & \multirow{2}{*}{$P, \%$} & \multicolumn{2}{|c|}{ Copolymer composition, \% } \\
\cline { 3 - 5 } & & & polyHEMA & PVP \\
\hline $90: 10: 70$ & $88 / 99$ & $5 / 8$ & $95 / 92$ & $5 / 8$ \\
\hline $80: 20: 70$ & $79 / 98$ & $9 / 15$ & $91 / 85$ & $9 / 15$ \\
\hline $70: 30: 70$ & $75 / 90$ & $10 / 19$ & $90 / 81$ & $10 / 19$ \\
\hline
\end{tabular}

Notes: ultrasound capacity is $120 \mathrm{~W}$; values in numerator are for WS, in denominator - for MM

Dependence of grafting parameters on the components ratio in the initial mixture

\begin{tabular}{|c|c|c|c|c|}
\hline \multirow{2}{*}{ HEMA:PVP:HA, wt.parts } & \multirow{2}{*}{$f, \%$} & \multirow{2}{*}{$P, \%$} & \multicolumn{2}{|c|}{ Copolymer composition, $\%$} \\
\hline & & & polyHEMA & PVP \\
\hline $90: 10: 70$ & 77 & 4 & 96 & 4 \\
\hline $80: 20: 70$ & 69 & 7 & 93 & 7 \\
\hline $70: 30: 25$ & $69 / 50$ & $12 / 10$ & $88 / 90$ & $12 / 10$ \\
\hline $70: 30: 70$ & $62 / 43$ & $8 / 7$ & $92 / 93$ & $8 / 7$ \\
\hline 70:30:100 & $58 / 33$ & $5 / 4$ & $95 / 96$ & $5 / 4$ \\
\hline $70: 30: 100 *$ & 68 & 6 & 94 & 6 \\
\hline
\end{tabular}
treatment

Notes: ultrasound capacity is $120 \mathrm{~W}$, for $* 180 \mathrm{~W}$; values in denominator are given for the composites without ultrasonic 
Similar results are observed when HA is used: with the increase in PVP content the efficiency of grafting decreases, and the degree of grafting increases (Table 3). However, we observe the significantly lower values of $f$ compared with other fillers (Table 2) and less notable dependence on the PVP content compared to the mixtures containing montmorillonite.

The most noticeable effect of PVP initial content on the efficiency of grafting when using MM is apparently due to the difference in polymerization mechanisms $[2,8]$. In this case the polymerization is predominantly carried out via the ionic mechanism.

In addition to the effect of HEMA:PVP ratio, the content of the mineral filler in the initial mixture also affects the composition of the formed copolymers (Table $3)$. With the increase in the filler amount, both the efficiency of grafting and the degree of grafting decrease. The PVP content in the copolymer decreases more than twice if the amount of the filler is increased from 25 to 100 wt.parts.

Under the action of ultrasound and with the increase in its intensity, the degree and efficiency of grafting increase, which can be used as one of the technological parameters for directed regulation of the composition of copolymers, and, consequently, their properties.

The obtained ultrasonic-treated composites have a pronounced porous structure, which is confirmed by TEM image (Fig. 3).

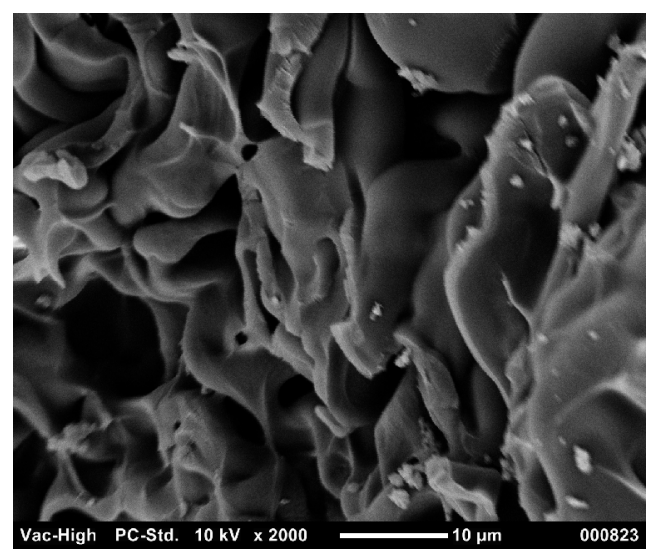

Fig. 3. Structure image of the composite with HA
The main properties of the porous composites depending on the nature and amount of filler are given in Table 4.

If porous material is not formed without $\mathrm{HA}$ and ultrasonic treatment, then under the action of the ultrasound it is formed even without the filler, though its porosity is low (entry 1 , Table 4).

Ultrasound in all cases contributes to the formation of a porous material, although with a smaller pore diameter. For the same amount of filler the smallest pore diameter was found in the case of MM use. The composites with WS have the largest pore diameter and the lowest mechanical parameters.

The obtained results were used during the development of the process flow diagram for the production of porous composites (Fig. 4).

The technological process can be divided into three main cycles: reagents treatment and preparation of the mixture, polymerization with simultaneous foaming of the composite and finishing operations. The main stage of the technological process is polymerization with the simultaneous formation of the porous structure. This process is similar to the technology of products casting without pressure.

2-Hydroxyethyl methacrylate (monomer) from a volumetric tank 1 is fed to the mixer 10 . When the stirrer is switched on, the initiator is loaded into the mixer from the weighing tank 2, PVP is supplied from 3 , and a foam stabilizer (PEG) - from 4. The components are dissolved in the mixer at room temperature. After complete dissolution of the components the mineral filler is fed from the doser 5 . The resulting mixture is fed into the mixer 11. A porous former (if necessary) is fed to the mixer by the doser 8 , and a solution of silver nitrate (if it is necessary to provide the composites with the fungal and bacterial properties) - from the mixer 9. The solution of silver nitrate is obtained by dissolving $\mathrm{AgNO}_{3}$ from the weighing tank 6 in a small amount of water supplied from the volumetric tank 7 . The resulting mixture from 11 is loaded into a paper or wood mold 12 and treated with an ultrasound, resulting in the mixture foaming and hardening. The finished blocks 14 are removed from the mold and directed for a mechanical treatment.

Table 4

Effect of nature and amount of filler on the composite properties

\begin{tabular}{|c|c|c|c|c|}
\hline $\begin{array}{c}\text { Nature and amount of } \\
\text { filler, wt } \%\end{array}$ & Porosity, $\%$ & $\begin{array}{c}\text { Pore average diameter, } \\
d_{p}, \mathrm{~mm}\end{array}$ & $\begin{array}{c}\text { Specific density } \rho_{\text {spec }}, \\
\mathrm{kg} / \mathrm{m}^{3}\end{array}$ & $\begin{array}{c}\text { Compression } \\
\text { strength, MPa }\end{array}$ \\
\hline 0 & $19 /$ pores are not formed & $0.16 /-$ & $1034 / 1235$ & 8.6 \\
\hline HA; 70 & $73 / 68$ & $0.51 / 0.93$ & 519 & 10.3 \\
\hline HA; 100 & $75 / 67$ & $0.86 / 1.40$ & 553 & 10.1 \\
\hline MM; 70 & $79 / 75$ & $0.49 / 0.79$ & 501 & 10.5 \\
\hline WS; 70 & $74 / 69$ & $0.62 / 1.03$ & 598 & 9.1 \\
\hline
\end{tabular}

Notes: HEMA:PVP = 70:30 (w/w), ultrasound capacity is $120 \mathrm{~W}$, synthesis time is $180 \mathrm{~s}$; values in denominator are given for the composites without ultrasonic treatment 

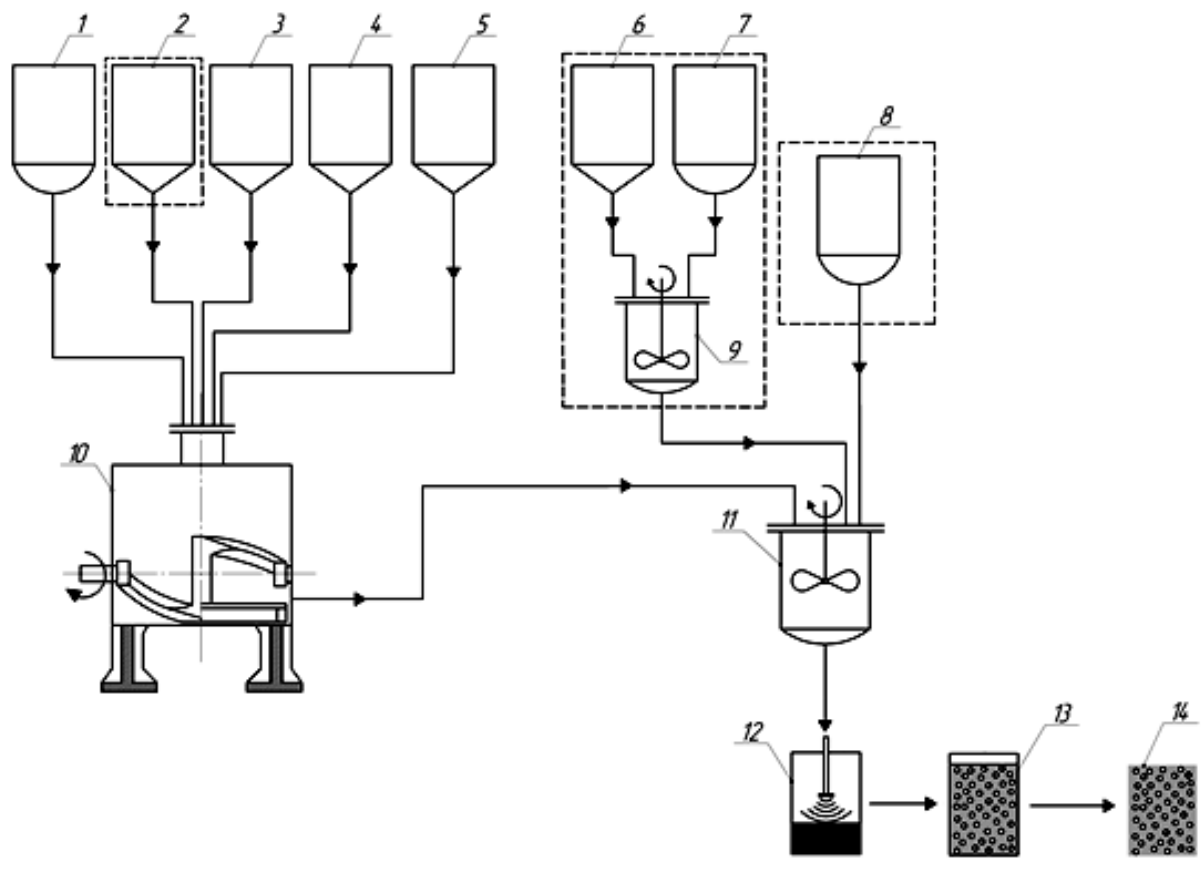

Fig. 4. The process flow diagram for the porous composites production: HEMA, water and cyclopentane volumetric tanks $(1,7,8)$; initiator, PVP, $\mathrm{PEG}$, mineral filler and $\mathrm{AgNO}_{3}$ weighing tanks $(2,3,4,5,6)$; mixers $(9-11)$; mold with the initial mixture (12); mold with porous composite (13) and porous block (14)

The proposed technological scheme will allow to produce the composite billets of arbitrary dimensions, which can be given the desired shape and size after mechanical treatment. This is important when using composites as bone implants. The use of medical ultrasonic devices opens up the possibility of forming a porous osteoplast directly in the patient's bone.

\section{Conclusions}

Thus, it has been established that ultrasound significantly intensifies the process of obtaining composites based on 2-hydroxyethyl methacrylate copolymers with polyvinylpyrrolidone, and filled with fine mineral fillers. The nature of the filler considerably affects the polymerization kinetics of HEMA-PVP mixtures, the composition of copolymer and the composite structure and properties. The developed composites have a porous structure and are recommended to be used as osteoplastic materials. The process flow diagram has been proposed for obtaining composites under ultrasonic treatment.

\section{Acknowledgements}

The work was carried out with the financial support of the state budget theme DB/PVP.

\section{References}

[1] Koval I., Shevchuk L., Starchevskyy V.: Chem. Eng. Transact., 2011, 24, 1315. https://doi.org/10.3303/CET1124220

[2] Skorokhoda V., Melnyk Yu., Semenyuk N., Suberlyak O.:

Chem. Chem. Technol., 2015, 9, 55.

https://doi.org/10.23939/chcht09.01.055

[3] Chen D., Sharma S., Mudhoo A.: Handbook on Application of Ultrasound. CRC Press, London New York 2011.

[4] Haider S., Haider A.: Hydrogels. IntechOpen, London 2018. https://doi.org/10.5772/intechopen.688817

[5] Suberlyak O., Semenyuk N., Dudok G., Skorokhoda V.: Rus. J. Appl. Chem., 2012, 85, 830.

https://doi.org/10.1134/S1070427212050254

[6] Skorokhoda V., Melnyk Y., Shalata V. et al.: East Eur. J.

Enterprise Techn., 2017, 1, 50.

[7] Suberlyak O., Melnyk Y., Skorokhoda V.: Mater. Sci., 2015, 50, 889. https://doi.org/10.1007/s11003-015-9798-8

[8] Skorokhoda V., Semenyuk N., Dziaman I. et al.: Voprosy Khim. i Khim. Tekhnol., 2018, 2, 101.

[9] Skorokhoda V., Semenyuk N., Dziaman I., Suberlyak O.: Chem. Chem. Technol., 2016, 10, 187.

https://doi.org/10.23939/chcht10.02.187

[10] Lee J., Kim K., Kim T. et al.: J. Porous Mater., 2013, $20,719$. https://doi.org/10.1007/s10934-012-9646-2

[11] Semenyuk N., Kostiv U., Suberlyak O., Skorokhoda V.: Chem. Chem. Technol., 2013, 7, 95.

https://doi.org/10.23939/chcht07.01.095

[12] Selyakova V., Kachevarova Y.: Metody Analiza Akrilatov i Metakrilatov. Khimiya, Moskva 1982.

[13] Dubyaga V., Perepechkin L., Katalevskyi E.: Polimernye Membrany. Khimiya, Moskva 1981. 
[14] Suberlyak O., Skorokhoda V., Thir I.: Vysokomol. Soed., 1989, 5B, 336.

[15] Suberlyak O., Levitskij V., Skorokhoda V., Godij A.: Ukr. Khim. Zh., 1998, 64, 122.

Received: January 20, 2019/Revised: January 28, 2019/ Accepted: March 30, 2019

\section{ВПЛИВ УЛЬТРАЗВУКУ НА ЗАКОНОМІРНОСТІ \\ ОДЕРЖАННЯ ТА ВЛАСТИВОСТІ ОСТЕОПЛАСТИЧНИХ ПОРИСТИХ КОМПОЗИТІВ}

Анотація. Досліджено прищеплену кополімеризацію 2-гідроксіетилметакрилату до полівінілпіролідону у присут- ності мінеральних наповнювачів (гідроксіапатиту, монтморилоніту $і$ воластоніту) під дією ультразвуку. Встановлено вплив ультразвуку, природи та кількості мінерального наповнювача на швидкість полімеризачиї і склад кополімерів. Ультразвук суттєво інтенсифікує процес полімеризаиії та активно впливає на формування складу кополімерів. Під його дією формується пористіша структура композитів навіть без використання спеціальних спінювальних агентів. Отримані результати були використані для вдосконалення технології одержання остеопластичних пористих композитів.

Ключові слова: 2-гідроксіетилметакрилат, полівінілпіролідон, ультразвук, пористі композити, мінеральний наповнювач. 